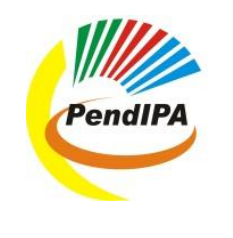

\title{
ANALISIS PENGARUH FAKTOR DEMOGRAFI TERHADAP LAMA KARANTINA PADA PERAWAT TERPAPAR COVID-19 DI JAWA TENGAH
}

\author{
Tri Winugroho $^{1 *}$, Mulya Imansyah ${ }^{1}$, Ernalem Bangun ${ }^{1}$, Rio Khoirudin Apriyadi ${ }^{1}$, \\ Arip Hidayat ${ }^{2}$ \\ ${ }^{1}$ Program Studi Manajemen Bencana, Universitas Pertahanan, Bogor \\ ${ }^{2}$ Program Studi Kesehatan Masyarakat, Universitas Hasanudin, Makasar \\ *Email: twinugroho@gmail.com \\ DOI: https://doi.org/10.33369/pendipa.5.2.229-236
}

\begin{abstract}
[Analysis Of The Effect Of Demographic Factors Towards Long Qarantine Of Nurses Exposed By Covid-19 In Central Java] Nurses as health workers at the forefront of the Covid-19 pandemic tend to be very prone to suffer physical and mental health problems due to workloads and also other factors during the Covid-19 pandemic. This study aims to determine the effect of demographic factors on the length of the quarantine period for nurses exposed to Covid-19 by using a quantitative descriptive technique and a cross sectional approach. The google form questionnaire method is used as an instrument in data collection and processed utilize chi square analysis. The results showed that of the 91 respondents with varying age distributions, the majority were 36-40 years old (30.8\%), female (71.4\%), the educational background was diploma (57.1\%), the majority were married. (81\%), occupied the position of nurse (89\%). With an average income of IDR 2,000,000-IDR 4,999,999 (58.5\%), the majority of nurses have 3-5 dependents (41\%) and most of the respondents live in the southern region of Central Java (63.7\%). Place of quarantine variable, the results showed that some respondents with no symptoms or mild symptoms were advised to selfquarantine at home (65.9\%). This provides a sense of security and calm for the respondent which influences psychological factors, thereby accelerating the quarantine period in addition to paying attention to other factors outside the research. By getting $p$ value of 0.019>0.05, it is concluded that the place of quarantine has an influence on the quarantine period for nurses exposed to Covid-19.
\end{abstract}

Keywords: Demographic factors, Nurses, Length of quarantine, Covid-19.

\begin{abstract}
ABSTRAK
Perawat sebagai tenaga kesehatan garda terdepan pandemi Covid-19 cenderung sangat rawan menderita gangguan kesehatan baik fisik maupun mental akibat beban kerja dan juga faktor lain di saat pandemic Covid-19. Penelitian ini bertujuan mengetahui pengaruh faktor demografi terhadap lamanya masa karantina pada Perawat ynag terpapar Covid-19 dengan menggunakan Teknik deskriptif kuantitif dan pendekatan cross sectional. Metode kuesioner google form digunakan sebagai intrumen dalam pengumpulan data dan diolah dengan memanfaatkan analisa chi square. Hasil penelitian didapatkan dari 91 respoden dengan sebaran usia bervariasi dengan umur terbanyak 36-40 tahun $(30,8 \%)$, jenis kelamin mayoritas perempuan $(71,4 \%)$, latar belakang Pendidikan diploma $(57,1 \%)$, mayoritas telah menikah $(81 \%)$, menduduki posisi perawat pelaksana $(89 \%)$. Dengan rerata penghasilan Rp.2.000.000-Rp.4.999.999 (58,5\%), mayoritas perawat memiliki jumlah tanggungan 3-5 orang (41\%) dan Sebagian besar dari responden tinggal diwilayah Selatan jawa Tengah $(63,7 \%)$. Pada variable tempat karantina didapatkan hasil bahwa sebagian dari respoden dengan tanpa gejala atau gejala ringan disarankan karantina mandiri dirumah (65,9\%). Hal ini memberikan rasa aman dan tenang bagi responden yang mempengaruhi faktor psikis sehingga mempercepat masa karantina disamping
\end{abstract}


memperhatikan faktor lain diluar penelitian. nilai $p 0,019>0,05$ yang diperoleh dari penelitian ini menyimpulkan bahwa tempat karantina memberi pengaruh terhadap masa karantina pada perawat yang terpapar covid-19.

Kata Kunci: Faktor demografi, Perawat, Lama karantina, Covid-19.

\section{PENDAHULUAN}

Covid-19 telah menjadi bencana pandemi dengan level penyebaran dan tingkat severity yang memprihatinkan. Hal ini lah oleh WHO sejak 11 Maret 2020 ditetapkan sebagai pandemic global. Muncul adanya fakta dari gelombang kedua penyebaran pandemic ini dengan penyebaran yang sangat cepat atas kasus baru yang terkonfirmasi di luar China, yaitu beberapa negara di Eropa seperti Amerika Utara, Asia serta Timur Tengah (Bedford et al., 2020)

Virus corona merupakan penyakit yang sangat mudah menular (contagious). Sebutan contagion mengarah pada infeksi yang menular dengan cepat dan masuk melalui jaringan, seperti bencana atau flu, (Mona, 2020), setelah itu akan terjadi penyebaran dan melewati saluran nafas bagian bawah. Masa perkembangbiakan tunas virus sampai muncul tanda-tanda tertular 3-7 hari.(PDPI, 2020)

WHO telah menyepakati ada empat skema dalam penilaian risiko nasional terhadap penyebaran Covid-19, yakni: negara-negara tanpa kasus konfirmasi positif, kasus pertama, klaster pertama, dan negara-negara dengan penularan lokal. Untuk itu, setiap negara harus memperkuat tindakan kesiapsiagaan dan reaksi tanggap darurat yang segera dan memadai, termasuk kesiapan infrastruktur kesehatan dan interaksi sosial masyarakat. Indonesia telah masuk pada skema ke empat dengan dikonfirmasi kasus positif akibat penularan secara lokal di beberapa wilayah, diantara Jakarta (Ghiffari, 2020) dan juga termasuk Kota Jawa Tengah.

Indonesia menyatakan kasus Covid-19 menjadi bencana nasional non alam pada 13 April 2020 . Kementerian Kesehatan melalui Satgas Covid-19 melaporkan adanya trend peningkatan jumlah kasus per hari dimana hingga 23 Januari 2021 jumlah pasien terkonfirmasi Covid-19 sebanyak 951.651 orang dengan korban jiwa 27.203 orang (Covid-19, 2020).
Yang dihadapi Indonesia saat ini tidak hanya trend peningkatan jumlah kasus, baik angka morbiditas maupun mortalitas namun yang disebabkan oleh karena jadanya stigma yang muncul dari komunitas baik kepada pasien maupun tenaga kesehatan maupun faktor psikologis dari tenaga kesehatan.

Penelitian sebaran pasien Covid-19 berdasarkan karakteristik umur dimana perbandingan tertinggi pasien Covid-19 di Indonesia berada pada rentang umur 50-59 tahun yang secara keseluruhan adalah sebesar 20,9 persen dari semua kasus terkonfirmasi Covid -19. Kemudian diikuti dengan kelompok usia dewasa muda, yaitu sebesar 16,5 persen positif untuk kelompok usia 40-49 tahun dan 15,9 persen dari kelompok usia 30-39 tahun. Sementara itu, penderita Covid -19 dari kelompok usia yang lebih tua, yaitu 60-69 tahun sebesar 12,7 persen. Seiring dengan waktu, proporsi kelompok usia 40-49 tahun mulai meningkat di Periode Kedua.(Vermonte \& Wicaksono, 2020).

Adanya sekelompok individu/kelompok masyarakat yang memberikan stigmatisasi pada petugas Kesehatan maupun pasien Covid-19 justru menimbulkan tren terjadinya peningkatan mortalitas dan morbiditas kasus Covid-19. Hal inilah yang menyebabkan pasien dan juga perawat sebagai tenaga kesehatan garda terdepan pandemi Covid-19 cenderung sangat rawan menderita gangguan kesehatan baik fisik maupun mental akibat stigma yang mereka terima baik oleh perawat sebagai pemberi layanan kesehatan maupun bagi pasien dengan Covid-19.

Pada 4 Januari 2021, Ikatan Dokter Indonesia memberikan pengumuman sesuai dengan fakta yang ada bahwa di Indonesia terdapat 504 tenaga kesehatan yang gugur ditengah pandemic yang terdidi dari 237 dokter (umum dan spesialis) dan 15 dentist, 171 nurse, 64 bidan, 7 ahli farmasi, 10 tenaga teknis laboran. (Kompas, 2021)

Hal ini adalah sebuah ironi yang harus mendapatkan penghargaan khusus dari 
pemerintah. Karena tenaga kesehatan seperti dokter, bidan, mantri maupun tenaga teknis rumah sakit lainya bersedia mendedikasikan dirinya untuk memberikan pelayanan kesehatan di komunitas dan bahkan mengorbankan jiwa dan raganya serta mengesampingkan sanak saudaranya demi membantu penanganan penyebaran Covid-19. Tenaga Kesehatan merupakan sebuah pekerjaan yang agung dan dengan pekerjaan tersebut semakin menunjukkan aktualisasinya pada bencana pandemi Covid-19 saat ini.(Pesulima \& Hetharie, 2020)

Perawat merupakan tenaga kesehatan yang memiliki peran yang sangat penting saat terjadi bencana. Karena perawat yang bekerja 24 jam untuk memantau perkembangan dan memberikan perawatan kesehatan bagi pasien Covid-19. Masyarakat, pemerintah dan lembaga swadaya masyarakat telah menyadari pentingnya kesiapsiagaan tenaga kesehatan khususnya perawat rumah sakit dalam menghadapi bencana, menjaga kesehatan dan keselamatan pasien serta memberikan pelayanan kesehatan yang menyeluruh dalam menjalankan tugasnya

Seorang individu mungkin akan berespon terhadap strees dengan berbagai cara mereka jika individu tersebut dalam keadaan darurat. Beberapa gejala yang mengindikasikan gangguan psikologis antara lain meningkatnya kecemasan, perubahan suasana hati, impuls rendah, dan pikiran gelisah atau tertekan. Pada saat masa karantina dirumah diberlakukan, peningkatan kecemasan akan dialami oleh masyarakat selama pandemi Covid-19 serta dapat berdampak serius pada kesehatan mental. (Brooks et al., 2020)

Dalam kasus ini, perawat yang mungkin terpapar karena adanya masalah psikososial yang timbul dari ambiguitas keadaan tempat kerja sekarang dan kedepannya atau dari proses transisi dan aturan kerja. Yang lebih mengkhawatirkan, masih banyak pemicu yang dialami tenaga kesehatan selama pandemi ini yang dapat menimbulkan stres, antara lain rasa takut pada diri sendiri atau keluarganya serta pasangan kerja yang mungkin tertular Covid-19; alat pelindung diri minimal; kurangnya dukungan sosial; munculnya perdebatan tentang aturan yang diberlakukan dan harapan untuk merawat atau mengakomodasi individu; ketidakmampuan dalam aktivitas seharihari seperti gerak badan, makan teratur dan rehat

https://ejournal.unib.ac.id/index.php/pendipa yang cukup (International Labour Organization, 2020).

Perawat dalam melaksanakan tanggung jawab dan tugasnya mutlak memerlukan persiapan baik fisik maupun psikologis. Ditempat kerja yang tidak menyenangkan ditambah dengan perilaku pasien akan membuat perawat kehilangan konsentrasi. Sesuatu yang kemungkinan akan meimbulkan stress dan konflik pada diri perawat merupakan tekanan yang harus segara diatasi.(Permatasari \& Utami, 2018)

Perasaan yang tidak mendukung, kondisi kesehatan personal yang tidak baik, kuatir menjadi sumber infeksi dan menyebarkankan kepada sanak saudara atau orang lain,merasa terisolasi, respon tidak nyaman, labelisasi sosial, kewajiban kerja yang overload, dan rasa tidak aman dan nyaman saat melakukan pelayanan perawatan dan kesehatan pada individu yang terpapar Covid-19 merupakan faktor risiko lain yang dapat di identifikasikan. (Rosyanti \& Hadi, 2020).

Sebuah penelitian menjelaskan bahwa isolasi diri dan karantina yang pernah dialami seorang individu akan berdampak adanya perubahan substansial pada tingkat kecemasan, emosi, kegugupan dan tekanan mental. Di sisi lain, masyarakat yang berada di luar tempat individu melakukan karantina / isolasi tentunya akan mengalami ketakutan dan kecemasan tertular karena kurangnya pengetahuan yang terbatas atau tidak tepat tentang Covid-19. Hal tersebut diungkapkan oleh (Brooks et al., 2020).

Namun beberapa waktu sebelumnya penelitian yang terpublikasikan bahwa kondisi pandemi yang disebabkan oleh infeksi virus yang memiliki gejala seperti sindrom SARS mirip dengan pandemi Covid-19 yang sedang terjadi ternyata memiliki dampak psikologis dan mental yang serius pada tenaga kesehatan dan masyarakat umum, termasuk kecemasan, depresi, dan gejala psikotik. (Luo et al., 2020).

Penelitian yang membahas tentang karakteristik pasien dihubungkan dengan lama rawat inap menunjukkan pasien dengan penyakit demam berdarah rerata dirawat selama tiga sampai empat belas hari dengan spesifikasi umur adalah usia muda dengan prosentase $(71,2 \%)$ dan pasien pria $(66,7 \%)$. Dengan menggunakan analisa chi square untuk menentukan ada tidaknya asosiasi gender dengan LOS (Length of Stay) diperoleh nilai $\mathrm{p}=$ 
0,019 dan untuk menentukan ada tidaknya hubungan usia dengan lama dirawat didapatkan $p$ value 0,017 . Dengan demikian ada korelasi antara lama dirawat dengan karakteristik orang sakit demam berdarah.(Fitri et al., 2011)

Dengan dasar tersebut diatas, riset ini mempunyai sasaran untuk menganalisis lama karantina/isolasi berdasarkan faktor demografi (umur,jenis kelamin,jumlah tanggungan, status perkawinan, pendapatan, tempat karantina, pendidikan dan posisi/jabatan) pada perawat yang terpapar Covid-19 di Jawa Tengah

Dengan latar belakang diatas maka tujuan dilakukan penelitian untuk mengetahui hubungan dengan demografi (usia, gender, pendidikan, posisi jabatan, jumlah tanggungan, tempat karantina, dan pendapatan) dengan lama masa karantina perawat yang terpapar Covid-19 di Jawa Tengah. Penelitian ini dilaksanakan pada kurun waktu Desember 2020-januari 2021.

\section{METODE PENELITIAN}

Studi yang digunakan adalah deskriptif kuantitatif dengan pendekatan cross sectional. Sampel yang digunakan yang berprofesi sebagai perawat di Jawa Tengah yang terpajan Covid-19 berjumlah 91 responden dengan teknik total sampling. Peneliti membagi sampel menjadi 4 wilayah yaitu wilayah Barat,Timur, Selatan dan Utara Jawa tengah.

Penelitian ini menggunakan kuesioner google form sebagai intrumen dalam pengumpulan data dimana angket akan dianalisa secara univariat dan bivariat (uji chisquare). Penelitian ini dilakukan pada periode Desember 2020-2021.

\section{HASIL DAN PEMBAHASAN}

Dari tabel 1 dapat dijelaskan bahwa distribusi umur pada responden diatas cukup merata, umur 36-40 tahun merupakan responden yang memiliki frekuensi terbanyak yaitu 28 responden $(30,8 \%)$ kemudian 19 responden berumur 26-30 tahun (20,9\%). Responden dengan jenis kelamin perempuan merupakan responde yang mayoritas dengan prosentase $71,4 \%$ dengan Pendidikan mayoritas Diploma $(57,1 \%)$ dengan rata-rata responden telah menikah (89\%) dan menduduki posisi sebagai perawat pelaksana $(96,7 \%)$ dengan rata-rata penghasilan Rp.2.000.000-Rp.4.999.999 $(58,5 \%)$. Jumlah tanggungan didalam keluarga sebanyka 4-5 orang (35\%) merupakan jumlah tanggungan yang menduduki responden terbanyak.

Tabel 1. Distribusi Frekuensi Karakteristik Individu

\begin{tabular}{|c|c|c|}
\hline Variabel & $\mathbf{n}$ & $\begin{array}{c}\text { Persentase } \\
\%\end{array}$ \\
\hline \multicolumn{3}{|l|}{ Umur } \\
\hline $21-25$ & 5 & $5,5 \%$ \\
\hline $26-30$ & 19 & $20,9 \%$ \\
\hline $31-35$ & 17 & $18,7 \%$ \\
\hline $36-40$ & 28 & $30,8 \%$ \\
\hline $41-45$ & 13 & $16,5 \%$ \\
\hline $46-50$ & 3 & $3,3 \%$ \\
\hline $51-55$ & 4 & $4,4 \%$ \\
\hline \multicolumn{3}{|l|}{ Jenis kelamin } \\
\hline Laki-laki & 26 & $28,6 \%$ \\
\hline Perempuan & 65 & $71,4 \%$ \\
\hline \multicolumn{3}{|l|}{ Pendidikan } \\
\hline SMA & 4 & $4,4 \%$ \\
\hline Diploma & 52 & $57,1 \%$ \\
\hline Sarjana & 34 & $34,4 \%$ \\
\hline Pascasarjana & 1 & $1,1 \%$ \\
\hline \multicolumn{3}{|l|}{ Status Perkawinan } \\
\hline Belum Kawin & 9 & $9,9 \%$ \\
\hline Kawin & 81 & $89 \%$ \\
\hline Cerai & 1 & $1,1 \%$ \\
\hline \multicolumn{3}{|l|}{ Posisi Jabatan } \\
\hline Pelaksana & 88 & $96,7 \%$ \\
\hline Kepala Ruang & 3 & $3,3 \%$ \\
\hline \multicolumn{3}{|l|}{ Penghasilan } \\
\hline$\leq$ Rp. 2.000 .000 & 22 & $24,2 \%$ \\
\hline Rp. 2.000.000 - & & \\
\hline Rp.4.999.999 & 55 & $58,5 \%$ \\
\hline Rp.5.000.000- & & \\
\hline 9.999 .999 & 14 & $15,4 \%$ \\
\hline$\geq$ Rp.10.000.000 & 2 & $2,2 \%$ \\
\hline \multicolumn{3}{|l|}{ Jumlah tanggungan } \\
\hline 0-1 Orang & 24 & $26,4 \%$ \\
\hline 2-3 Orang & 26 & $28,6 \%$ \\
\hline 4-5 orang & 41 & $35 \%$ \\
\hline \multicolumn{3}{|l|}{ Kategori wilayah } \\
\hline Selatan & 58 & $63,7 \%$ \\
\hline Utara & 6 & $6,6 \%$ \\
\hline Timur & 6 & $6,6 \%$ \\
\hline Barat & 21 & $23,1 \%$ \\
\hline \multicolumn{3}{|l|}{ Tempat Karantina } \\
\hline Rumah Sakit & 31 & $34,1 \%$ \\
\hline Rumah & 60 & $65,9 \%$ \\
\hline
\end{tabular}

Wilayah sebaran responden mayoritas ada diwilayah Selatan $(63,7 \%)$ dan 65,9\% mayoritas responden yang terpapar covid disarankan untuk 
isolasi mandiri.

Tabel 2. Distribusi Deskripsi lama Karantina

\begin{tabular}{lcllll}
\hline Variabel & Mean & Median SD & Min & Max \\
\hline $\begin{array}{l}\text { Lama } \\
\text { Karan } \\
\text { tina }\end{array}$ & 16,84 & 14,00 & 10,608 & 3 & 62 \\
\hline
\end{tabular}

Dari tabel 2 di atas disimpulkan bahwa rata-rata masa karantina perawat yang terpapar covid 16,84 hari dibulatkan 17 hari dengan 3 hari sebagai masa karantina terpendek dan 62 hari sebagai masa karantina yang paling lama diantara responden yang lain.

Tabel 3. Distribusi Hubungan faktor umur,jenis kelamin,Pendidikan, status perkawinan, Jabatan, penghasilan, jumlah tanggungan, tempat karantina, dan kategori wilayah terhadap lama waktu karantina/isolasi.

\begin{tabular}{lc}
\hline Variabel & P Value \\
Umur & \\
$21-25$ & \\
$26-30$ & 0.937 \\
$31-35$ & \\
$36-40$ & \\
$41-45$ & \\
$46-50$ & \\
$51-55$ & 0,338 \\
\hline Jenis kelamin & \\
Laki-laki & \\
Perempuan & 0,700 \\
\hline Pendidikan & \\
SMA & \\
Diploma & \\
Sarjana & \\
Pascasarjana & \\
\hline Status Perkawinan & \\
Belum Kawin & \\
Kawin & \\
Cerat & \\
\hline Posisi Jabatan & \\
Pelaksana & \\
Kepala Ruang & \\
\hline Penghasilan & \\
Kurang Rp. & \\
\end{tabular}

2.000 .000

Rp. 2.000 .000

0,468

Rp.4.999.999

Rp.5.000.000-

9.999.999

Lebih

Rp. 10.000 .000

\begin{tabular}{ll}
\hline Jumlah tanggungan & \\
0-2 Orang & 0,588 \\
2-3 Orang & \\
4-5 orang & \\
\hline $\begin{array}{l}\text { Wilayah } \\
\text { Selatan } \\
\text { Utara } \\
\text { Timur } \\
\text { Barat }\end{array}$ & 0,245 \\
Tempat Karantina/Isolasi & \\
Rumah Sakit \\
Rumah
\end{tabular}

Pada tabel 3 dengan memperhatikan hasil uji analisis statistik uji Chi Square antara variabel umur, jenis kelamin, Pendidikan, status perwakinan, posisi jabatan, penghasilan, jumlah tanggungan serta tempat karantina semuanya menunjukkan tidak adanya pengaruh dari variabel-variabel tersebut terhadap lamanya waktu karantina pada Perawat yang terpapar Covid-19 di Jawa Tengah. Hal ini dapat ditunjukkan dari nilai $p$ value $>0,05$.

Responden yang terpapar Covid-19 yang tempat karantina mandirinya adalah dirumah merupakan responden terbanyak dengan jumlah 60 orang $(65,9 \%)$ dengan nilai $p 0,019<0,05$. Ini dapat disimpulkan jika tempat karantina mempunyai pengaruh yang cukup signifikan terhadap lama masa karantina.

\section{PEMBAHASAN}

Hasil dari Penelitian ini menggambarkan bahwa tidak ada pengaruh usia dengan lama waktu karantina/isolasi pada Perawat yang terpapar Covid-19 di Jawa Tengah. Antara umur 26-45 merupakan usia dewasa dengan pertimbangan individu dengan umur tersebut akan mempunyai mindset yang cukup baik sehingga pola pikir akan informasi yang dimilikinya juga akan semakin membaik.

Faktor lain yang dapat menghalangi adalah 
keadaan fisik dan psikis seseorang seperti kondisi seseorang ketika sakit atau ada keterbatasan dalam indra. Tidak adanya pengaruh umur dengan lama masa karantina pencegahan Covid19 kemungkinan dapat dikarenakan adanya perbandingan yang hampir sama antara kelompok umur remaja, dewasa dan lansia awal dengan pola pikir yang cukup baik.

Umur bukan menjadi faktor penghambat untuk mempunya pola pikir dalam mendapatkan sumber informasi mengenai Covid-19, karena komunitas tertentu dengan kelompok usia yang berbeda tersebut memungkinkan untuk memiliki ketekunan dan keterpaparan informasi yang sama (Nurmala, I, Rahman, F, Nugroho, A., Erlyani, N, Laily, N, Anhar, 2018).

Disamping itu di saat yang sama, kelompok usia mayoritas ini memiliki mobilitas yang relatif tinggi dengan riwayat perjalanan keluar kota yang juga lebih sering. (Vermonte \& Wicaksono, 2020)

Disisi lain, pada variabel lainnyapun tidak ditemukan bahwa ada pengaruh jenis kelamin dengan masa lamanya karantina pada perawat terpapar Covid.

Berdasarkan hasil penelitian, dapat disimpulkan bahwa perawat dengan jenis kelamin perempuan cenderung memiliki kerentanan terpapar Covid19 jika dikomparasikan dengan pria. Hal ini kemungkinan disebabkan oleh secara fisik, perempuan memiliki kondisi yang lemah dan juga faktor stressor yang cukup tinggi.

Perempuan cenderung mempunya perasaan yang lebih peka, sering mempunyai rasa tidak aman dan nyaman saat melakukan pelayanan perawatan dan kesehatan pada individu yang terpapar Covid-19 hal inilah yang merupakan resiko yang dapat diindentifikasi bagi seorang perawat. (Rosyanti \& Hadi, 2020).

Hal ini kontra dengan data orang sakit Covid-19 berdasarkan gender di Indonesia menjelaskan bahwa jumlah pasien pasien pria yang terpajan Covid-19 lebih besar jika dikomparasikan dengan perempuan (Covid-19, 2020).

Per tanggal 28 Mei 2020 data menunjukkan bahwa separuh dari orang yang positif Covid-19 merupakan pria $(55 \%)$. Paradigma ini terjadi hampir diseluruh wilayah di Indonesia. Bahkan, paradigma ini juga diketahui terjadi kasus yang sama di negara lain yang beranggapan jika pria lebih berisiko terpajan Covid-19. Risiko yang dihadapi oleh pria terkait dengan mobilitas pria yang lebih sering berada beraktivitas di luar dibanding wanita. (Begley, 2020).

Namun demikian pernyataan berdasarkan penelitian ini belum dapat dijadikan pijakan yang berhubungan dengan faktor jenis kelamin pada kasus Covid-19.(Wenham et al., 2020)

Pada variabel pendidikan, dalam penelitian ini tidak ada pengaruh pendidikan dengan lama waktu karantina pada perawat terpapar Covid-19. Hal ini disebabkan karena pengetahuan yang didapatkan oleh perawat dengan pendidikan yang mereka miliki mengenai penularan Covid-19 tidak hanya dari pendidikan formal namun juga dari pengalamannya (Muslima, T.K., Ernawaty, J., Woferst, 2012) selama mereka perawat Covid19 di tempat mereka bekerja.

Didalam penelitian ini menunjukkan bahwa tidak terdapat pengaruh status perkawinan, pendapatan, posisi jabatan, jumlah tanggungan dalam keluarga serta kategori wilayah terhadap lama masa karantina ada Perawat yang terpapar Covid19. Hal ini disebabkan kemungkinan karena secara psikis perawat tidak akan memikirkan faktor-faktor tersebut diatas. Mereka akan fokus bagi kesembuhan diri mereka karena penyakit ini harus diantisipasi karena penyebarannya yang relatif cepat, memiliki tingkat tingkat fatalitas yang tidak dapat diabaikan, dan belum adanya pengobatan yang akurat.(Wulandari et al., 2020) Hal ini sejalan dengan sebuah penelitian yang menjelaskan bahwa isolasi diri dan karantina yang pernah dialami seorang individu akan berdampak adanya perubahan substansial pada tingkat kecemasan, emosi, kegugupan dan tekanan mental.(Brooks et al., 2020)

Studi ini menunjukkan bahwa tenpat karantina berkontirubusi positif terhadap lama waktu karantina. Ini kemungkinan dapat dapat disebabkan sesuai dengan peraturan dari Kementerian Kesehatan bahwa individu yang terpapar Covid-19 dengan tanpa tanda atau dengan tanda sakit ringan dapat melakukan isolasi mandiri tanpa dirawat dengan protokol kesehatan yang ketat. Individu akan merasa nyaman jika meraka berada dilingkungan yang bagi mereka nyaman dan mendukung bagi proses penyembuhan.

\section{KESIMPULAN}

Tempat karantina memiliki pengaruh yang 
signifikan terhadap proses penyembuhan dan memperpendek masa karantina pada perawat yang terpapar Covid-19. Sedangkan umur, pendidikan, status perkawinan dan posisi dalam pekerjaan, wilayah,pendapatan serta jenis kelamin tidak memiliki kontribusi dalam mempengaruhi lama waktu karantina pada Perawat yang terpapar Covid-19.

Hasil ini selain dapat dipengaruhi oleh perbedaan kriteria pasien yang dirawat di rumah dan dirawat di rumah sakit berdasarkan Peraturan dari Kementrian Kesehatan juga dapat dipengaruhi oleh faktor psikis dimana orang yang terpapar covid tanpa gejala atau dengan gejala ringansedang akan merasa nyaman jika berada dilingkungan sendiri dengan menerapkan protokol kesehatan yang ketat dibandingkan dirawat di rumah sakit.

\section{UCAPAN TERIMA KASIH}

Terima kasih kepada rekan-rekan perawat RS dr. Kariadi Semarang, RS. Bhakti Wira Tamtama Semarang, RS Wijayakusuma Purwokerto,RSAU Lanud Jend. Sudirman Purwokerto, RS. Loekmono Hadi Kudus, RS. RAA Suwondo Pati, RSUD Demak, RS. NU Demak, RSUD Kraton Pekalongan, RS dr. Soehadi Prijonegoro Sragen, RSUP Surakarta, BKPM Surakarta dan RS. Dr. Soedjono Magelangyang telah meluangkan pikiran dan waktu untuk berkontribusi dalam penelitian ini di masa pandemi pada saat dilakukan penelitian ini. Tetap semangat dan salam Tangguh, salam sehat untuk semua perawat Indonesia.

\section{DAFTAR PUSTAKA}

Bedford, J., Enria, D., Giesecke, J., Heymann, D. L., Ihekweazu, C., Kobinger, G., Lane, H. C., Memish, Z., Oh, M. don, Sall, A. A., Schuchat, A., Ungchusak, K., \& Wieler, L. H. (2020). COVID-19: towards controlling of a pandemic. The Lancet, 395(10229), 10151018. https://doi.org/10.1016/S01406736(20)30673-5

Begley, S. (2020). Which Groups Are Most at
Risk from the Coronavirus? Scientific American Journal. https://doi.org/https://doi.org/10.1101/2020.0 2.17.20024166V3

Brooks, S. K., Webster, R. K., \& Smith, L. E. (2020). The psychological impact of quarantine and how to reduce it : Rapid review of the evidence. The Lancet Journal, $1-25$. https://doi.org/https://doi.org/10.1016/S01406736(20)30460-8

Covid-19, G. T. P. P. (2020). Peta Sebaran| Satgas Penanganan COVID-19. Https://Covid19.Go.Id/Peta-Sebaran.

Fitri, N., Susilo, Y., Sugiarsi, S., Nurifa, M., \& Kunci, K. (2011). Hubungan Karakteristik Pasien Dengan Lama Dirawat Pada Pasien Demam Berdarah Di Rsud Dr . Moewardi. 112.

Ghiffari, R. A. (2020). Dampak Populasi Dan Mobilitas Perkotaan Terhadap Penyebaran Pandemi Covid-19 Di Jakarta. Tunas Geografi, 9(1), 81. https://doi.org/10.24114/tgeo.v9i1.18622

International Labour Organization. (2020). Dalam menghadapi pandemi: Memastikan Keselamatan dan Kesehatan di Tempat Kerja. Labour Administration, Labour Inspection and Occupational Safety and Health Branch (LABADMIN/OSH) Route, 1-52.

Kompas. (2021, January 4). Kematian tenaga medis Indonesia akibat covid 1-tertinggi di Asia kenapa? Kompas. https://www.kompas.com/sains/read

Luo, M., Guo, L., Yu, M., Jiang, W., \& Wang, H. (2020). The psychological and mental impact of coronavirus disease 2019 (COVID19) on medical staff and general public - A systematic review and meta- analysis. Psychiatry Research Journal, April. https://doi.org/https://doi.org/10.1016/j.psychr es.2020.113190

Mona, N. (2020). Konsep Isolasi Dalam Jaringan Sosial Untuk Meminimalisasi Efek 
Contagious (Kasus Penyebaran Virus Corona Di Indonesia). Jurnal Sosial Humaniora Terapan, 2(2), 117-125. https://doi.org/10.7454/jsht.v2i2.86

Muslima, T.K., Ernawaty, J., Woferst, R. (2012). Faktor-Faktor Yang Mempengaruhi Tingkat Pengetahuan Orang Tua Terhadap Dampak Televisi Pada Perkembangan Anak Usia Sekolah. Universitas Riau.

Nurmala, I, Rahman, F, Nugroho, A., Erlyani, N, Laily, N, Anhar, V. (2018). Promosi Kesehatan. Airlangga University Press.

PDPI. (2020). Panduan Praktik Klinis:

Pneumonia 2019-nCoV. Persatuan Dokter

Paru Indonesia.

Permatasari, Y. D. A., \& Utami, M. S. (2018).

Koping Stres dan Stres pada Perawat di Rumah Sakit Jiwa "X." Psikologika: Jurnal Pemikiran Dan Penelitian Psikologi, 23(2), 121-136.

https://doi.org/10.20885/psikologika.vol23.iss 2.art4

Pesulima, T. L., \& Hetharie, Y. (2020). Perlindungan Hukum Terhadap Keselamatan Kerja Bagi Tenaga Kesehatan Akibat Pandemi Covid-19. Sasi, 26(2), 280. https://doi.org/10.47268/sasi.v26i2.307
Rosyanti, L., \& Hadi, I. (2020). Dampak Psikologis dalam Memberikan Perawatan dan Layanan Kesehatan Pasien COVID-19 pada Tenaga Profesional Kesehatan. Faktor Penyebab Stres Pada Tenaga Kesehatan Dan Masyarakat Pada Saat Pandemicovid-19, 12(1).

Vermonte, P., \& Wicaksono, T. Y. (2020). Karakteristik dan Persebaran COVID-19 di Indonesia : Temuan Awal. CSIS Commentaries DMRU-043-ID, April, 1-12.

Wenham, C., Smith, J., \& Morgan, R. (2020). COVID-19: the gendered impacts of the outbreak. The Lancet, 395(10227), 846-848. https://doi.org/10.1016/S01406736(20)30526-2.

Wulandari, A., Rahman, F., Pujianti, N., Sari, A. R., Laily, N., Anggraini, L., Muddin, F. I., Ridwan, A. M., Anhar, V. Y., Azmiyannoor, M., \& Prasetio, D. B. (2020). Hubungan Karakteristik Individu dengan Pengetahuan tentang Pencegahan Coronavirus Disease 2019 pada Masyarakat di Kalimantan Selatan. Jurnal Kesehatan Masyarakat Indonesia, 15(1), 42. https://doi.org/10.26714/jkmi.15.1.2020.4246. 